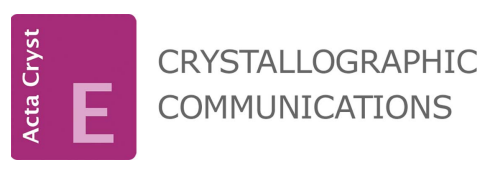

ISSN 2056-9890

Received 19 February 2017

Accepted 1 March 2017

Edited by C. Rizzoli, Universita degli Studi di Parma, Italy

Keywords: crystal structure; chalcone thiophene derivative; Hirshfeld surface analysis; in silico evaluation.

CCDC reference: 1535563

Supporting information: this article has supporting information at journals.iucr.org/e

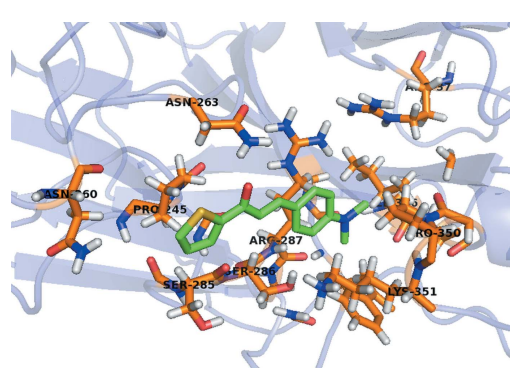

OPEN $\odot$ ACCESS

\section{Crystal structure of (2E)-3-[4-(dimethylamino)- phenyl]-1-(thiophen-2-yl)prop-2-en-1-one}

\author{
Gabriela Porto de Oliveira, ${ }^{a}$ Leandro Bresolin, ${ }^{\mathrm{a} *}$ Darlene Correia Flores, ${ }^{\text {a }}$ \\ Renan Lira de Farias ${ }^{\mathrm{b}}$ and Adriano Bof de Oliveira ${ }^{\mathrm{c}}$
}

\begin{abstract}
a Universidade Federal do Rio Grande (FURG), Escola de Química e Alimentos, Rio Grande, Brazil, ${ }^{\mathbf{b}}$ Universidade Estadual Paulista (UNESP), Instituto de Química, Araraquara, Brazil, and ' Universidade Federal de Sergipe (UFS), Departamento de Química, São Cristóvão, Brazil. *Correspondence e-mail: leandro_bresolin@yahoo.com.br
\end{abstract}

The equimolar reaction between 4-(dimethylamino)benzaldehyde and 2-acetylthiophene in basic ethanolic solution yields the title compound, $\mathrm{C}_{15} \mathrm{H}_{15} \mathrm{NOS}$, whose molecular structure matches the asymmetric unit. The molecule is not planar, the dihedral angle between the aromatic and the thiophene rings being $11.4(2)^{\circ}$. In the crystal, molecules are linked by $\mathrm{C}-$ $\mathrm{H}$. . O and weak C $-\mathrm{H} \cdots \mathrm{S}$ interactions along [100], forming $R_{2}^{2}(8)$ rings, and by weak $\mathrm{C}-\mathrm{H} \cdots \mathrm{O}$ interactions along [010], forming chains with a $C(6)$ graph-set motif. In addition, molecules are connected into centrosymmetric dimers by weak $\mathrm{C}-\mathrm{H} \cdots \pi$ interactions, as indicated by the Hirshfeld surface analysis. The most important contributions for the crystal structure are the $\mathrm{H} \cdots \mathrm{H}(46.50 \%)$ and $\mathrm{H} \cdots \mathrm{C}(23.40 \%)$ interactions. The crystal packing resembles a herringbone arrangement when viewed along [100]. A molecular docking calculation of the title compound with the neuraminidase enzyme was carried out. The enzyme shows $(A S N 263) \mathrm{N}-\mathrm{H} \cdots \mathrm{O}, \quad(P R O 245) \mathrm{C}-\mathrm{H} \cdots C g$ (thiophene ring) and $(A G R 287) \mathrm{C}-\mathrm{H} \cdots \mathrm{N}$ intermolecular interactions with the title compound. The crystal structure was refined as a two-component twin with a fractional contribution to the minor domain of 0.0181 (8).

\section{Chemical context}

Chalcone derivatives are compounds with an aromatic conjugated enone as the main fragment and are synthesized by hydroxide-catalysed aldol condensation between an aromatic aldehyde and a ketone. Some of the first preparative methods of the aldol condensation were reported in the second half of the 19th Century (Claisen \& Claparède, 1881; Schmidt, 1881) and the experimental procedure remains the same to the present time. Chalcone compounds can be obtained from a great number of starting materials, resulting in a class of compounds with a wide range of properties and applications, specially in the medicinal chemistry. Several 4-dialkylaminochalcones have shown antiproliferative activity on cancer cell lines and one method to monitor the chalcone-protein interaction, e.g. tubulin proteins, is the chalcone's fluorescence (Zhou et al., 2016). Another example of the pharmacological background for the title compound and its derivatives is the anti-influenza viral activity through the neuraminidase enzymatic inhibition in vitro (Kinger et al., 2012). Thus, the crystal structure determination of chalcone-based molecules is an intensive research area, in particular for its contributions in medicinal chemistry. As part of our studies in this field, we 
describe herein the crystal structure, the Hirshfeld surface analysis and the molecular docking evaluation of the title compound.<smiles>CN(C)c1ccc(/C=C/C(=O)c2cccs2)cc1</smiles>

\section{Structural commentary}

In the crystal structure of the title compound, a chalconethiophene derivative, the asymmetric unit contains one crystallographically independent molecule (Fig. 1). The molecule is not planar: the r.m.s deviations from the mean plane of the non-H atoms range from -0.158 (3) $\AA$ for C3 to 0.1318 (15) $\AA$ for S1 and the dihedral angle between the benzene and thiophene rings amounts to $11.4(2)^{\circ}$. In addition, the plane through the amino group atoms $(\mathrm{C} 7 / \mathrm{C} 8 / \mathrm{N} 1)$ is rotated by $9.7(6)^{\circ}$ with respect to the plane of the aromatic ring. Finally, the molecule shows the $E$ configuration about the $\mathrm{C} 9-\mathrm{C} 10$ bond.

\section{Supramolecular features}

In the crystal, the molecules are connected by very weak $\mathrm{C} 13-\mathrm{H} 13 \cdots \mathrm{O} 1^{\mathrm{i}}$ and $\mathrm{C} 14-\mathrm{H} 14 \cdots \mathrm{S} 1^{\mathrm{i}}$ hydrogen-bonding interactions (see Table 1 for symmetry codes), forming rings with an $R_{2}{ }^{2}(8)$ graph-set motif. The $R_{2}{ }^{2}(8)$ rings are the subunits of the periodic arrangement along [100] and one very weak $\mathrm{H} 7 \cdots \mathrm{H} 2^{\mathrm{i}}$ contact is also observed $[\mathrm{H} \cdots \mathrm{H}=2.26 \AA]$. The molecular units are also linked by very weak $\mathrm{C} 15-\mathrm{H} 15 \cdots \mathrm{O} 1^{\mathrm{ii}}$ links into chains along [010] with a $C(6)$ graph-set motif (Fig. 2; Table 1). Additionally, the molecules are connected into centrosymmetric dimers by very weak $\mathrm{C}-\mathrm{H} \cdots \pi$ interactions involving the thiophene ring (Fig. 3; Table 1). The intermolecular contacts are slightly longer than the sum of the van der Waals radii for the respective atoms (Bondi, 1964; Rowland \& Taylor, 1996) and suggest weak interactions only.

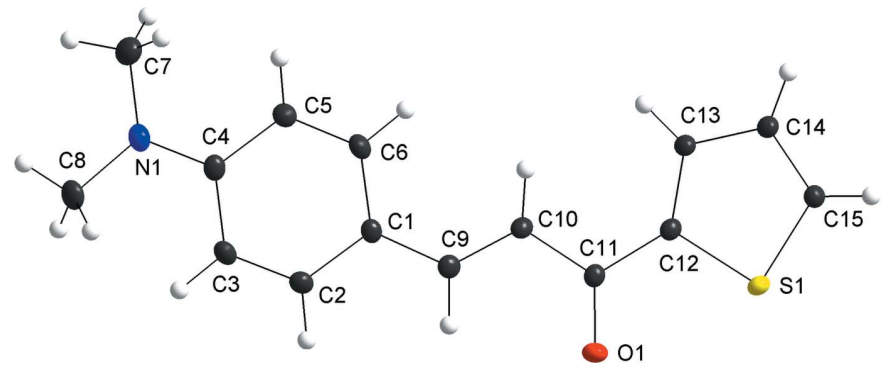

Figure 1

The molecular structure of the title compound, showing displacement ellipsoids drawn at the $40 \%$ probability level.
Table 1

Hydrogen-bond geometry $\left(\AA,^{\circ}\right)$.

$C g$ is the centroid of the $\mathrm{S} 1 / \mathrm{C} 12-\mathrm{C} 15$ thiophene ring.

\begin{tabular}{lllll}
\hline$D-\mathrm{H} \cdots A$ & $D-\mathrm{H}$ & $\mathrm{H} \cdots A$ & $D \cdots A$ & $D-\mathrm{H} \cdots A$ \\
\hline $\mathrm{C} 13-\mathrm{H} 13 \cdots \mathrm{O} 1^{\mathrm{i}}$ & 0.95 & 2.65 & $3.451(4)$ & 142 \\
$\mathrm{C} 14-\mathrm{H} 14 \cdots \mathrm{S}^{\mathrm{i}}$ & 0.95 & 3.00 & $3.779(3)$ & 141 \\
$\mathrm{C} 15-\mathrm{H} 15 \cdots \mathrm{O} 1^{\mathrm{ii}}$ & 0.95 & 2.57 & $3.291(4)$ & 133 \\
$\mathrm{C} 8-\mathrm{H} 8 \cdots \mathrm{Cg}^{\mathrm{iii}}$ & 0.98 & 2.64 & $3.457(4)$ & 141 \\
\hline
\end{tabular}

Symmetry codes: (i) $x+1, y, z$; (ii) $-x-\frac{1}{2}, y-\frac{1}{2},-z+\frac{3}{2}$; (iii) $-x,-y,-z+1$.

\section{Hirshfeld surface analysis}

The Hirshfeld surface analysis (Hirshfeld, 1977) of the crystal structure suggests that the contribution of the $\mathrm{H} \cdots \mathrm{H}$ intermolecular interactions to the crystal packing amounts to $46.50 \%$ and the contribution of the $\mathrm{H} \cdots \mathrm{C}$ interactions

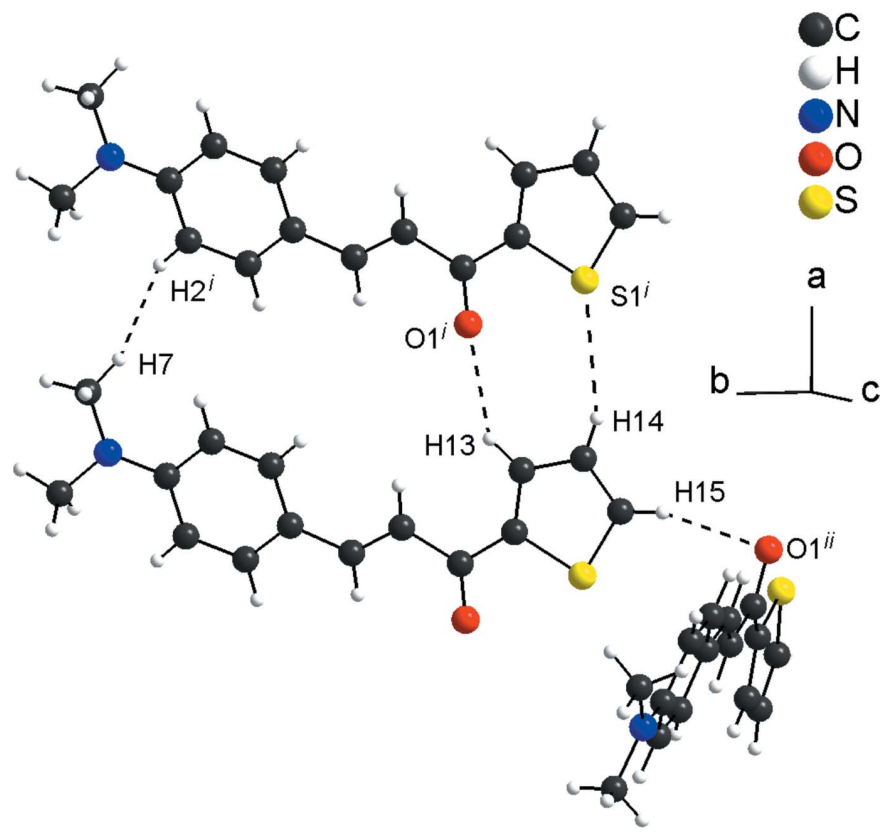

Figure 2

Graphical representation of the weak intermolecular $\mathrm{C}-\mathrm{H} \cdots \mathrm{O}, \mathrm{C}-$ $\mathrm{H} \cdots \mathrm{S}$ and $\mathrm{H} \cdots \mathrm{H}$ interactions (dashed lines) in the crystal structure of the title compound. [Symmetry codes: (i) $x+1, y, z$; (ii) $-x-\frac{1}{2}, y-\frac{1}{2},-z+\frac{3}{2}$.]

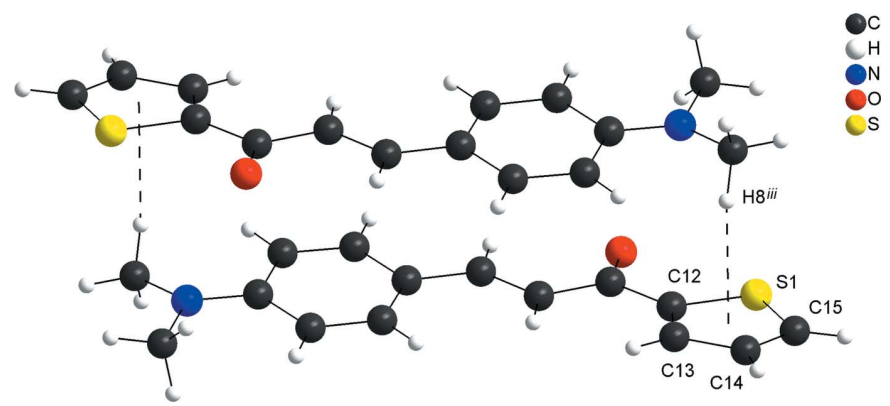

Figure 3

Graphical representation of the weak intermolecular $\mathrm{C}-\mathrm{H} \cdots \pi$ interactions (dashed lines) in the crystal structure of the title compound, forming a centrosymmetric dimer. [Symmetry code: (iii) $-x,-y,-z+1$.] 


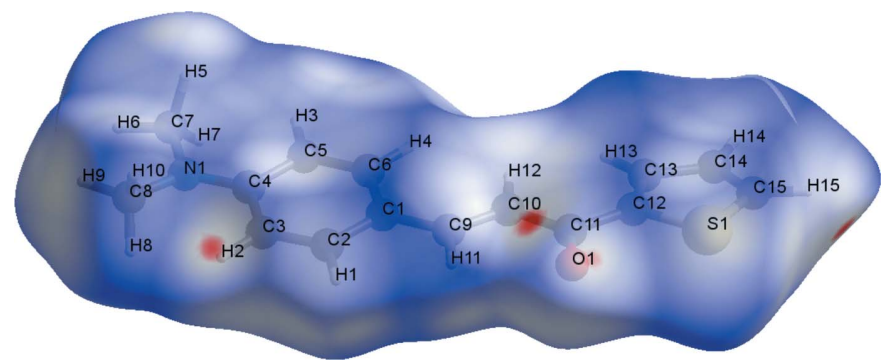

Figure 4

A graphical representation of the Hirshfeld surface $\left(d_{\text {norm }}\right)$ for the title compound. The surface is drawn with transparency and all atoms are labelled. The surface regions with strongest intermolecular interactions for atoms $\mathrm{H} 2, \mathrm{H} 15$ and $\mathrm{O} 1$ are shown in magenta.

amounts to $23.40 \%$. Other important intermolecular contacts for the cohesion of the structure are (values given in \%): $\mathrm{H} \cdots \mathrm{O}=10.80$ and $\mathrm{H} \cdots \mathrm{S}=10.00$. Graphical representations of the Hirshfeld surface with transparency and labelled atoms (Figs. 4 and 5) indicate, in a magenta colour, the locations of the strongest intermolecular contacts, e.g. the $\mathrm{H} 2, \mathrm{H} 7, \mathrm{H} 13$, $\mathrm{H} 15$ and $\mathrm{O} 1$ atoms. The $\mathrm{C}-\mathrm{H} \cdots \pi$ interaction is also well represented in the Hirshfeld surface (for details, compare Figs. 3 and 5). The $\mathrm{H} \cdots \mathrm{H}, \mathrm{H} \cdots \mathrm{C}, \mathrm{H} \cdots \mathrm{O}$ and $\mathrm{H} \cdots \mathrm{S}$ contributions to the crystal packing are shown as a Hirshfeld surface twodimensional fingerprint plot with cyan dots. The $d_{\mathrm{e}}(y$ axis) and $d_{\mathrm{i}}(x$ axis $)$ values are the closest external and internal distances (values given in $\AA$ ) from given points on the Hirshfeld surface contacts (Fig. 6; Wolff et al., 2012).

\section{Molecular docking evaluation}

In addition, a lock-and-key supramolecular analysis between the neuraminidase enzyme, whose inhibition is believed to be a key point to block the influenza viral infection (Kinger et al., 2012), and the title compound was performed. The semiempirical equilibrium energy of the title compound was obtained using the PM6 Hamiltonian and the experimental bond lengths were conserved. The calculated parameters were: heat of formation $=139.28 \mathrm{~kJ} \mathrm{~mol}^{-1}$, gradient normal $=$ $0.62031, \mathrm{HOMO}=-8.96 \mathrm{eV}, \mathrm{LUMO}=-0.866 \mathrm{eV}$ and energy gap $=7.421 \mathrm{eV}$ (Stewart, 2013). The rigid molecular docking was carried out with the GOLD software (Jones et al., 1997)

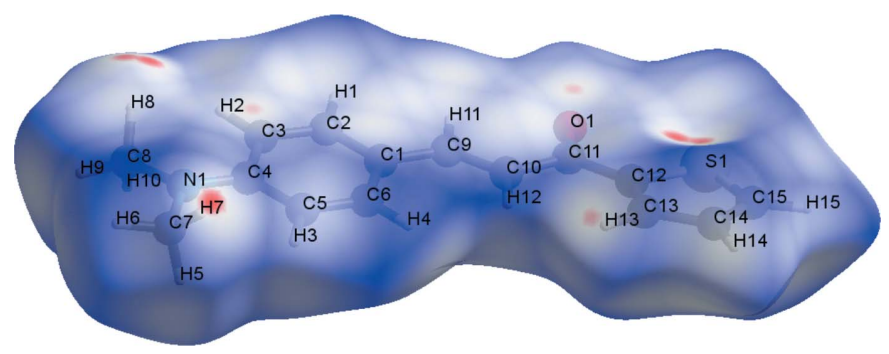

Figure 5

A graphical representation of the Hirshfeld surface $\left(d_{\text {norm }}\right)$ for the title compound. The surface is drawn with transparency and all atoms are labelled. The surface regions with strongest intermolecular interactions for atoms $\mathrm{H} 7, \mathrm{H} 8, \mathrm{H} 13$ and $\mathrm{O} 1$, and for the thiophene ring, are shown in magenta.
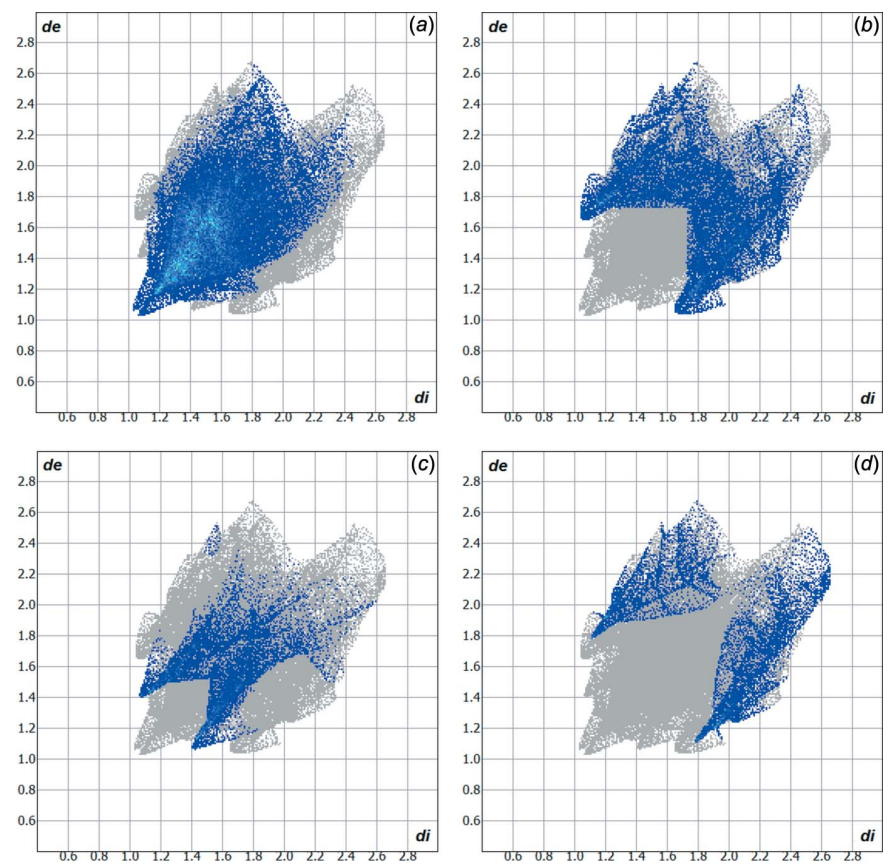

Figure 6

Hirshfeld surface two-dimensional fingerprint plots for the title compound showing the $(a) \mathrm{H} \cdots \mathrm{H},(b) \mathrm{H} \cdots \mathrm{C},(c) \mathrm{O} \cdots \mathrm{H}$ and $(d) \mathrm{H} \cdots \mathrm{S}$ contacts in detail (cyan dots). The contributions of the interactions to the crystal packing amount to $46.50,23.40,10.80$ and $10.00 \%$, respectively. The $d_{\mathrm{e}}\left(y\right.$ axis) and $d_{\mathrm{i}}(x$ axis) values are the closest external and internal distances (values in $\AA$ ) from given points on the Hirshfeld surface contacts.

using the ChemPLP score function (Chen, 2015). The chalcone thiophene derivative and the active site of the neuraminidase match (Fig. 7) and the structure-activity relationship can be assumed by the following observed intermolecular interactions $(\mathrm{H} \cdots \mathrm{A}$ distance values given in $\AA$ ): $($ ASN263 $) \mathrm{N}-\mathrm{H} \cdots \mathrm{O} 1 \quad(d=1.796), \quad($ PRO245 $) \mathrm{C}-$ $\mathrm{H} \cdots C g$ (thiophene ring $)(d=2.829)$ and $(A G R 287) \mathrm{C}-\mathrm{H} \cdots \mathrm{N} 1$ $(d=2.620)$ (Fig. 8). More details about the in silico evaluation, with additional references, can be found in the Supporting Information. For the intermolecular interactions, it is important to report that the $\mathrm{H} \cdots \mathrm{Cg}$ (thiophene ring) contact is observed in the structure interpretation, by the centrosymmetric dimeric arrangement of the molecules (Figs. 3 and 9), in the Hirshfeld surface analysis (Fig. 5) and in the molecular docking evaluation (Fig. 8).

\section{Database survey}

Chalcone-thiophene derivatives have some molecular structural features in common, namely the nearly planar geometry, as a result of the $s p^{2}$-hybridized $\mathrm{C}$ atoms of the main fragment, and the weak intermolecular interactions, e.g. $\mathrm{H} \cdots \mathrm{H}, \mathrm{H} \cdots \mathrm{C}$ or $\pi-\pi$ contacts. One example for comparison with the title compound is the crystal structure of the compound 3-(4methylphenyl)-1-(3-thienyl)-2-propen-1-one ( $\mathrm{Li} \& \mathrm{Su}, 1993$ ). In both of the structures, the molecules are linked by weak interactions into centrosymmetric dimers and the crystal 


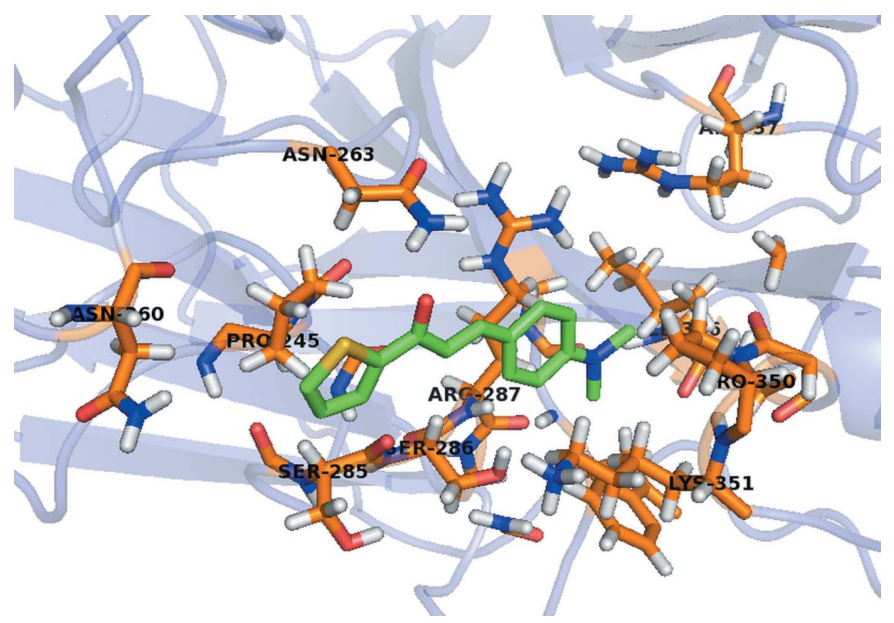

Figure 7

Graphical representation of the lock-and-key model for the title compound, with the molecular main fragment in green, and the neuraminidase structure, with selected amino acids residues, in stick model. The structure of the enzyme is simplified for clarity.

packing shows a herringbone motif: for the title compound this molecular arrangement is clear when looking along the [100] direction (Fig. 9a) and for the above-mentioned 3-thienyl derivative, along [001] (Fig. 9b).

\section{Synthesis and crystallization}

All starting materials are commercially available and were used without further purification. The synthesis of the title compound was adapted from a previously reported procedure (Claisen \& Claparède, 1881; Schmidt, 1881; Zhou et al., 2016). In a hydroxide-catalysed reaction, a mixture of 4-(dimethylamino)benzaldehyde $(10 \mathrm{mmol})$ and 2-acetylthiophene $(10 \mathrm{mmol})$ in ethanol $(80 \mathrm{~mL})$ was stirred under room temperature for $4 \mathrm{~h}$. After cooling in an ice bath and filtering,

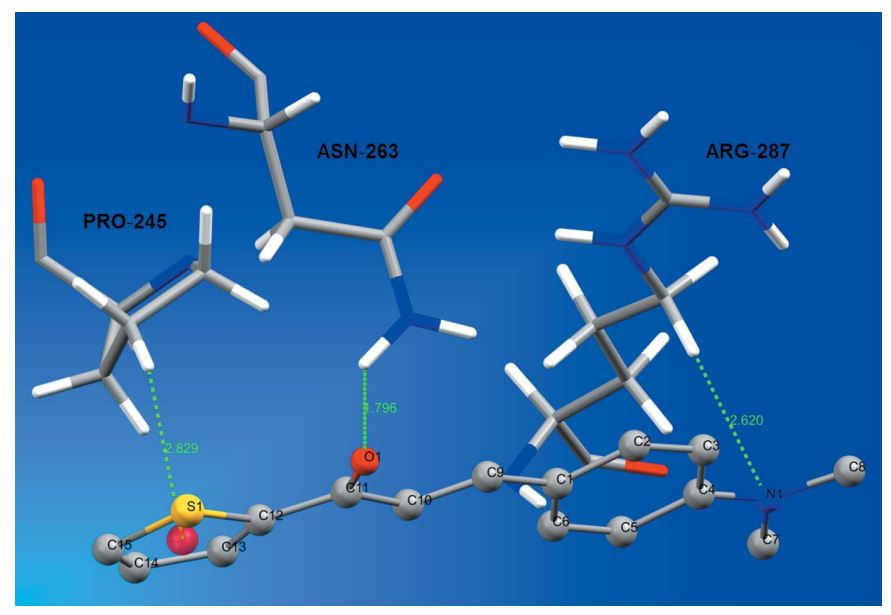

Figure 8

Intermolecular interactions between the title compound and the neuraminidase enzyme. The interactions are shown as dashed lines and the structure of the enzyme is simplified for clarity.

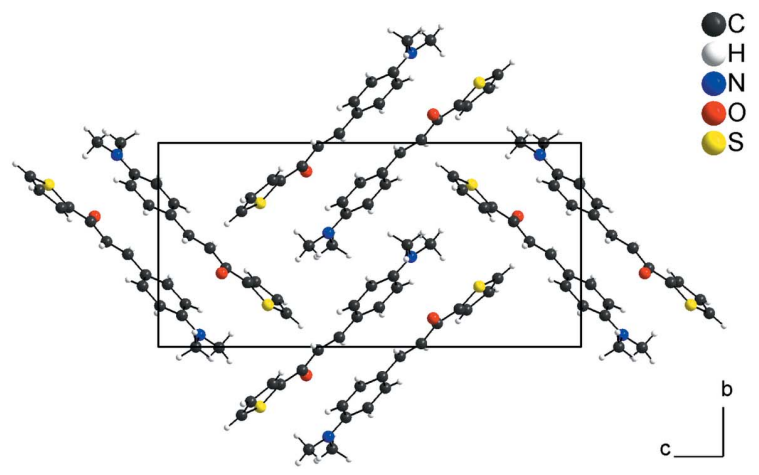

(a)

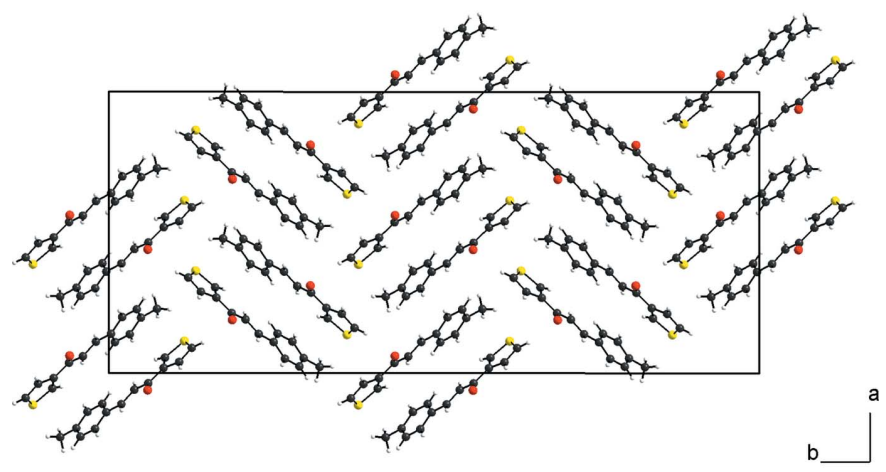

Figure 9

(b)

Section of the crystal structures of $(a)$ the title compound viewed along [100], and (b) the 3-(4-methylphenyl)-1-(3-thienyl)-2-propen-1-one compound ( $\mathrm{Li} \& \mathrm{Su}, 1993)$ viewed along [001], showing the herringbone motif.

an orange solid was obtained. Orange crystals were grown from the solution after $24 \mathrm{~h}$.

\section{Refinement}

Crystal data, data collection and structure refinement details are summarized in Table 2. $\mathrm{H}$ atoms were located in a difference-Fourier map but were positioned with idealized geometry and were refined with isotropic displacement parameters using a riding model (HFIX command) with $U_{\text {iso }}(\mathrm{H})=$ $1.2 U_{\text {eq }}(\mathrm{C})$ or $1.5 U_{\text {eq }}(\mathrm{C})$ for methyl $\mathrm{H}$ atoms. A rotating model was used for the methyl groups. The crystal was refined as a two-component twin \{twin law: two-axis (001) [105], BASF = $0.0181(8)\}$.

\section{Acknowledgements}

$\mathrm{ABO}$ is an associate researcher in the project 'Dinitrosyl complexes containing thiol and/or thiosemicarbazone: synthesis, characterization and treatment against cancer', founded by FAPESP, Proc. 2015/12098-0, and acknowledges Professor José C. M. Pereira (UNESP, Brazil) for his support. GPO thanks CNPq for the MSc scholarship and RLF thanks the CAPES foundation for the PhD scholarship. The authors acknowledge Professor Manfredo Hörner for access to 
Table 2

Experimental details.

\begin{tabular}{|c|c|}
\hline \multicolumn{2}{|l|}{ Crystal data } \\
\hline Chemical formula & $\mathrm{C}_{15} \mathrm{H}_{15} \mathrm{NOS}$ \\
\hline$M_{\mathrm{r}}$ & 257.34 \\
\hline Crystal system, space group & Monoclinic, $P 2_{1} / n$ \\
\hline Temperature (K) & 120 \\
\hline$a, b, c(\AA)$ & $6.2405(4), 9.9975(6), 20.7815(13)$ \\
\hline$\beta\left({ }^{\circ}\right)$ & $93.097(2)$ \\
\hline$V\left(\AA^{3}\right)$ & $1294.65(14)$ \\
\hline$Z$ & 4 \\
\hline Radiation type & Mo $K \alpha$ \\
\hline$\mu\left(\mathrm{mm}^{-1}\right)$ & 0.24 \\
\hline Crystal size $(\mathrm{mm})$ & $0.53 \times 0.16 \times 0.09$ \\
\hline \multicolumn{2}{|l|}{ Data collection } \\
\hline Diffractometer & $\begin{array}{l}\text { Bruker APEXII CCD area } \\
\text { detector }\end{array}$ \\
\hline Absorption correction & $\begin{array}{l}\text { Multi-scan (SADABS; Bruker, } \\
\text { 2014) }\end{array}$ \\
\hline$T_{\min }, T_{\max }$ & $0.885,0.979$ \\
\hline $\begin{array}{l}\text { No. of measured, independent and } \\
\text { observed }[I>2 \sigma(I)] \text { reflections }\end{array}$ & $50820,3381,3116$ \\
\hline$R_{\text {int }}$ & 0.031 \\
\hline$(\sin \theta / \lambda)_{\max }\left(\AA^{-1}\right)$ & 0.677 \\
\hline \multicolumn{2}{|l|}{ Refinement } \\
\hline$R\left[F^{2}>2 \sigma\left(F^{2}\right)\right], w R\left(F^{2}\right), S$ & $0.068,0.182,1.14$ \\
\hline No. of reflections & 3381 \\
\hline No. of parameters & 166 \\
\hline $\mathrm{H}$-atom treatment & $\mathrm{H}$-atom parameters constrained \\
\hline$\Delta \rho_{\max }, \Delta \rho_{\min }\left(\mathrm{e} \AA^{-3}\right)$ & $1.16,-0.81$ \\
\hline
\end{tabular}

Computer programs: APEX2 and SAINT (Bruker, 2014), SHELXS97 (Sheldrick, 2008), SHELXL2016 (Sheldrick, 2015), WinGX (Farrugia, 2012), DIAMOND (Brandenburg, 2006), GOLD (Chen et al., 2015), Crystal Explorer (Wolff et al., 2012), publCIF (Westrip, 2010) and enCIFer (Allen et al., 2004). experimental facilities and Guilherme Alves de Moraes for the data collection (Federal University of Santa Maria, Brazil).

\section{References}

Allen, F. H., Johnson, O., Shields, G. P., Smith, B. R. \& Towler, M. (2004). J. Appl. Cryst. 37, 335-338.

Bondi, A. (1964). J. Phys. Chem. 68, 441-451.

Brandenburg, K. (2006). DIAMOND. Crystal Impact GbR, Bonn, Germany.

Bruker (2014). APEX2, SADABS and SAINT. Bruker AXS Inc., Madison, Wisconsin, USA.

Chen, Y.-C. (2015). Trends Pharmacol. Sci. 36, 78-95.

Claisen, L. \& Claparède, A. (1881). Chem. Ber. 14, 2460-2468.

Farrugia, L. J. (2012). J. Appl. Cryst. 45, 849-854.

Hirshfeld, H. L. (1977). Theor. Chim. Acta, 44, 129-138.

Jones, G., Willett, P., Glen, R. C., Leach, A. R. \& Taylor, R. (1997). J. Mol. Biol. 267, 727-748.

Kinger, M., Park, Y. D., Park, J. H., Hur, M. G., Jeong, H. J., Park, S. J., Lee, W. S., Kim, S. W. \& Yang, S. D. (2012). Arch. Pharm. Res. 35, 633-638.

Li, Z. \& Su, G. (1993). Acta Cryst. C49, 1075-1077.

Rowland, R. S. \& Taylor, R. (1996). J. Phys. Chem. 100, 7384-7391.

Schmidt, J. G. (1881). Chem. Ber. 14, 1459-1461.

Sheldrick, G. M. (2008). Acta Cryst. A64, 112-122.

Sheldrick, G. M. (2015). Acta Cryst. C71, 3-8.

Stewart, J. J. (2013). J. Mol. Model. 19, 1-32.

Westrip, S. P. (2010). J. Appl. Cryst. 43, 920-925.

Wolff, S. K., Grimwood, D. J., McKinnon, J. J., Turner, M. J., Jayatilaka, D. \& Spackman, M. A. (2012). Crystal Explorer. University of Western Australia, Perth, Australia.

Zhou, B., Jiang, P., Lu, J. \& Xing, C. (2016). Arch. Pharm. Chem. Life Sci. 349, 539-552. 


\section{supporting information}

Acta Cryst. (2017). E73, 476-480 [https://doi.org/10.1107/S2056989017003437]

Crystal structure of (2E)-3-[4-(dimethylamino) phenyl]-1-(thiophen-2-yl) prop-2-

en-1-one

Gabriela Porto de Oliveira, Leandro Bresolin, Darlene Correia Flores, Renan Lira de Farias and Adriano Bof de Oliveira

Computing details

Data collection: APEX2 (Bruker, 2014); cell refinement: SAINT (Bruker, 2014); data reduction: SAINT (Bruker, 2014); program(s) used to solve structure: SHELXS97 (Sheldrick, 2008); program(s) used to refine structure: SHELXL2016 (Sheldrick, 2015) and WinGX (Farrugia, 2012); molecular graphics: DIAMOND (Brandenburg, 2006), GOLD (Chen et al., 2015) and Crystal Explorer (Wolff et al., 2012); software used to prepare material for publication: publCIF (Westrip, 2010) and enCIFer (Allen et al., 2004).

(2E)-3-[4-(Dimethylamino) phenyl]-1-(thiophen-2-yl)prop-2-en-1-one

Crystal data

$\mathrm{C}_{15} \mathrm{H}_{15} \mathrm{NOS}$

$M_{r}=257.34$

Monoclinic, $P 2{ }_{1} / n$

$a=6.2405(4) \AA$

$b=9.9975(6) \AA$

$c=20.7815(13) \AA$

$\beta=93.097(2)^{\circ}$

$V=1294.65(14) \AA^{3}$

$Z=4$

Data collection

Bruker APEXII CCD area detector diffractometer

Radiation source: fine-focus sealed tube, Bruker APEXII CCD area detector

$\varphi$ and $\omega$ scans

Absorption correction: multi-scan

(SADABS; Bruker, 2014)

$T_{\min }=0.885, T_{\max }=0.979$

Refinement

Refinement on $F^{2}$

Least-squares matrix: full

$R\left[F^{2}>2 \sigma\left(F^{2}\right)\right]=0.068$

$w R\left(F^{2}\right)=0.182$

$S=1.14$

3381 reflections

166 parameters
$F(000)=544$

$D_{\mathrm{x}}=1.320 \mathrm{Mg} \mathrm{m}^{-3}$

Mo $K \alpha$ radiation, $\lambda=0.71073 \AA$

Cell parameters from 9620 reflections

$\theta=2.3-28.7^{\circ}$

$\mu=0.24 \mathrm{~mm}^{-1}$

$T=120 \mathrm{~K}$

Block, orange

$0.53 \times 0.16 \times 0.09 \mathrm{~mm}$

50820 measured reflections

3381 independent reflections

3116 reflections with $I>2 \sigma(I)$

$R_{\text {int }}=0.031$

$\theta_{\text {max }}=28.8^{\circ}, \theta_{\min }=2.3^{\circ}$

$h=-7 \rightarrow 8$

$k=-13 \rightarrow 13$

$l=-28 \rightarrow 28$

0 restraints

Primary atom site location: structure-invariant direct methods

Secondary atom site location: difference Fourier map

Hydrogen site location: inferred from neighbouring sites 
H-atom parameters constrained

$w=1 /\left[\sigma^{2}\left(F_{\mathrm{o}}^{2}\right)+7.019 P\right]$

where $P=\left(F_{\mathrm{o}}^{2}+2 F_{\mathrm{c}}^{2}\right) / 3$

$$
\begin{aligned}
& (\Delta / \sigma)_{\max }<0.001 \\
& \Delta \rho_{\max }=1.16 \mathrm{e} \AA^{-3} \\
& \Delta \rho_{\min }=-0.81 \mathrm{e} \AA^{-3}
\end{aligned}
$$

Special details

Geometry. All esds (except the esd in the dihedral angle between two 1.s. planes) are estimated using the full covariance matrix. The cell esds are taken into account individually in the estimation of esds in distances, angles and torsion angles; correlations between esds in cell parameters are only used when they are defined by crystal symmetry. An approximate (isotropic) treatment of cell esds is used for estimating esds involving 1.s. planes.

\begin{tabular}{|c|c|c|c|c|}
\hline & $x$ & $y$ & $z$ & $U_{\text {iso }} * / U_{\text {eq }}$ \\
\hline $\mathrm{C} 1$ & $-0.1108(5)$ & 0.1473 & $0.52979(15)$ & $0.0159(6)$ \\
\hline $\mathrm{C} 2$ & $-0.2422(5)$ & $0.1940(4)$ & $0.47768(16)$ & $0.0189(6)$ \\
\hline H1 & -0.382513 & 0.157938 & 0.471036 & $0.023 *$ \\
\hline $\mathrm{C} 3$ & $-0.1753(5)$ & $0.2904(4)$ & $0.43572(15)$ & $0.0193(6)$ \\
\hline $\mathrm{H} 2$ & -0.269640 & 0.319201 & 0.401045 & $0.023 *$ \\
\hline $\mathrm{C} 4$ & $0.0319(5)$ & $0.3467(3)$ & $0.44378(15)$ & $0.0178(6)$ \\
\hline $\mathrm{C} 5$ & $0.1659(5)$ & 0.2992 & $0.49602(16)$ & $0.0188(6)$ \\
\hline H3 & 0.306383 & 0.334799 & 0.502939 & $0.023^{*}$ \\
\hline C6 & $0.0956(5)$ & 0.2024 & $0.53690(15)$ & $0.0181(6)$ \\
\hline $\mathrm{H} 4$ & 0.190279 & 0.171734 & 0.571104 & $0.022 *$ \\
\hline $\mathrm{C} 7$ & $0.3103(6)$ & $0.5007(4)$ & $0.4112(2)$ & $0.0295(8)$ \\
\hline H5 & 0.318786 & 0.553158 & 0.451058 & $0.044^{*}$ \\
\hline H6 & 0.336378 & 0.559200 & 0.374572 & $0.044 *$ \\
\hline $\mathrm{H} 7$ & 0.418747 & 0.429736 & 0.413870 & $0.044^{*}$ \\
\hline $\mathrm{C} 8$ & $-0.0527(6)$ & $0.5041(4)$ & $0.35627(17)$ & $0.0241(7)$ \\
\hline H8 & -0.117365 & 0.435643 & 0.327624 & $0.036^{*}$ \\
\hline H9 & 0.021999 & 0.570086 & 0.330728 & $0.036^{*}$ \\
\hline H10 & -0.165267 & 0.548805 & 0.379384 & $0.036^{*}$ \\
\hline $\mathrm{C} 9$ & $-0.1918(5)$ & $0.0467(3)$ & $0.57189(15)$ & $0.0168(6)$ \\
\hline H11 & -0.336808 & 0.020903 & 0.562907 & $0.020 *$ \\
\hline $\mathrm{C} 10$ & $-0.0899(5)$ & $-0.0158(3)$ & $0.62222(15)$ & $0.0163(6)$ \\
\hline H12 & 0.056053 & 0.004730 & 0.633416 & $0.020^{*}$ \\
\hline C11 & $-0.2021(5)$ & -0.1147 (3) & $0.65969(15)$ & $0.0164(6)$ \\
\hline $\mathrm{C} 12$ & $-0.0788(5)$ & -0.1847 (3) & $0.71167(15)$ & $0.0155(6)$ \\
\hline $\mathrm{C} 13$ & $0.1366(5)$ & $-0.1816(3)$ & $0.72937(15)$ & $0.0174(6)$ \\
\hline H13 & 0.237533 & -0.126760 & 0.709136 & $0.021 *$ \\
\hline $\mathrm{C} 14$ & $0.1911(5)$ & $-0.2697(3)$ & $0.78141(16)$ & $0.0194(6)$ \\
\hline H14 & 0.333099 & -0.281313 & 0.799380 & $0.023^{*}$ \\
\hline $\mathrm{C} 15$ & $0.0180(5)$ & $-0.3357(3)$ & $0.80267(15)$ & $0.0180(6)$ \\
\hline H15 & 0.024715 & -0.397159 & 0.837576 & $0.022 *$ \\
\hline N1 & $0.0994(5)$ & $0.4417(3)$ & $0.40233(14)$ & $0.0232(6)$ \\
\hline $\mathrm{O} 1$ & $-0.3960(4)$ & -0.1393 & $0.65025(12)$ & $0.0220(5)$ \\
\hline $\mathrm{S} 1$ & $-0.21315(13)$ & $-0.29494(9)$ & $0.75923(4)$ & $0.0187(2)$ \\
\hline
\end{tabular}

Refinement. Refined as a 2-component twin.

Fractional atomic coordinates and isotropic or equivalent isotropic displacement parameters $\left(\AA^{2}\right)$ 
Atomic displacement parameters $\left(\AA^{2}\right)$

\begin{tabular}{lllllll}
\hline & $U^{11}$ & $U^{22}$ & $U^{33}$ & $U^{12}$ & $U^{13}$ & $U^{23}$ \\
\hline C1 & $0.0188(14)$ & $0.0149(14)$ & $0.0140(14)$ & $0.0025(12)$ & $0.0012(11)$ & $-0.0014(11)$ \\
C2 & $0.0160(14)$ & $0.0211(16)$ & $0.0195(15)$ & $0.0028(12)$ & $0.0003(12)$ & $-0.0010(13)$ \\
C3 & $0.0187(15)$ & $0.0221(16)$ & $0.0167(14)$ & $0.0051(13)$ & $-0.0014(12)$ & $0.0004(13)$ \\
C4 & $0.0226(16)$ & $0.0152(14)$ & $0.0159(14)$ & $0.0039(12)$ & $0.0030(12)$ & $-0.0011(12)$ \\
C5 & $0.0200(15)$ & $0.0170(15)$ & $0.0191(15)$ & $-0.0006(12)$ & $-0.0011(12)$ & $-0.0016(12)$ \\
C6 & $0.0211(15)$ & $0.0179(15)$ & $0.0148(14)$ & $0.0020(13)$ & $-0.0029(11)$ & $-0.0011(12)$ \\
C7 & $0.0287(19)$ & $0.0276(19)$ & $0.032(2)$ & $-0.0026(16)$ & $0.0024(15)$ & $0.0082(16)$ \\
C8 & $0.0300(18)$ & $0.0202(16)$ & $0.0220(16)$ & $0.0055(14)$ & $-0.0009(14)$ & $0.0054(13)$ \\
C9 & $0.0190(15)$ & $0.0161(14)$ & $0.0156(14)$ & $0.0017(12)$ & $0.0027(11)$ & $-0.0033(12)$ \\
C10 & $0.0172(14)$ & $0.0158(14)$ & $0.0159(14)$ & $-0.0027(12)$ & $0.0011(11)$ & $-0.0025(12)$ \\
C11 & $0.0183(14)$ & $0.0159(14)$ & $0.0150(14)$ & $0.0004(12)$ & $0.0023(11)$ & $-0.0018(11)$ \\
C12 & $0.0168(14)$ & $0.0146(14)$ & $0.0154(14)$ & $-0.0017(11)$ & $0.0030(11)$ & $-0.0020(11)$ \\
C13 & $0.0165(14)$ & $0.0174(15)$ & $0.0182(15)$ & $-0.0029(12)$ & $0.0004(11)$ & $0.0020(12)$ \\
C14 & $0.0176(14)$ & $0.0202(16)$ & $0.0203(15)$ & $-0.0023(12)$ & $0.0011(12)$ & $0.0047(13)$ \\
C15 & $0.0184(15)$ & $0.0199(15)$ & $0.0157(14)$ & $-0.0009(12)$ & $0.0001(11)$ & $0.0010(12)$ \\
N1 & $0.0267(15)$ & $0.0216(14)$ & $0.0211(14)$ & $0.0009(12)$ & $-0.0012(12)$ & $0.0062(12)$ \\
O1 & $0.0145(11)$ & $0.0256(13)$ & $0.0258(12)$ & $-0.0025(10)$ & $-0.0014(9)$ & $0.0034(10)$ \\
S1 & $0.0137(4)$ & $0.0218(4)$ & $0.0210(4)$ & $-0.0023(3)$ & $0.0030(3)$ & $0.0038(3)$ \\
& & & & & &
\end{tabular}

Geometric parameters $\left(\AA,{ }^{\circ}\right)$

\begin{tabular}{llll}
\hline $\mathrm{C} 1-\mathrm{C} 6$ & $1.401(5)$ & $\mathrm{C} 8-\mathrm{H} 8$ & 0.9800 \\
$\mathrm{C} 1-\mathrm{C} 2$ & $1.403(4)$ & $\mathrm{C} 8-\mathrm{H} 9$ & 0.9800 \\
$\mathrm{C} 1-\mathrm{C} 9$ & $1.442(4)$ & $\mathrm{C} 8-\mathrm{H} 10$ & 0.9800 \\
$\mathrm{C} 2-\mathrm{C} 3$ & $1.379(5)$ & $\mathrm{C} 9-\mathrm{C} 10$ & $1.348(5)$ \\
$\mathrm{C} 2-\mathrm{H} 1$ & 0.9500 & $\mathrm{C} 9-\mathrm{H} 11$ & 0.9500 \\
$\mathrm{C} 3-\mathrm{C} 4$ & $1.412(5)$ & $\mathrm{C} 10-\mathrm{C} 11$ & $1.461(4)$ \\
$\mathrm{C} 3-\mathrm{H} 2$ & 0.9500 & $\mathrm{C} 10-\mathrm{H} 12$ & 0.9500 \\
$\mathrm{C} 4-\mathrm{N} 1$ & $1.364(4)$ & $\mathrm{C} 11-\mathrm{O} 1$ & $1.240(4)$ \\
$\mathrm{C} 4-\mathrm{C} 5$ & $1.416(5)$ & $\mathrm{C} 11-\mathrm{C} 12$ & $1.469(4)$ \\
$\mathrm{C} 5-\mathrm{C} 6$ & $1.375(5)$ & $\mathrm{C} 12-\mathrm{C} 13$ & $1.375(4)$ \\
$\mathrm{C} 5-\mathrm{H} 3$ & 0.9500 & $\mathrm{C} 12-\mathrm{S} 1$ & $1.728(3)$ \\
$\mathrm{C} 6-\mathrm{H} 4$ & 0.9500 & $\mathrm{C} 13-\mathrm{C} 14$ & $1.422(4)$ \\
$\mathrm{C} 7-\mathrm{N} 1$ & $1.445(5)$ & $\mathrm{C} 13-\mathrm{H} 13$ & 0.9500 \\
$\mathrm{C} 7-\mathrm{H} 5$ & 0.9800 & $\mathrm{C} 14-\mathrm{C} 15$ & 0.9500 \\
$\mathrm{C} 7-\mathrm{H} 6$ & 0.9800 & $\mathrm{C} 14-\mathrm{H} 14$ & $1.709(3)$ \\
$\mathrm{C} 7-\mathrm{H} 7$ & 0.9800 & $\mathrm{C} 15-\mathrm{S} 1$ & 0.9500 \\
$\mathrm{C} 8-\mathrm{N} 1$ & $1.452(4)$ & $\mathrm{C} 15-\mathrm{H} 15$ & 109.5 \\
& & & 109.5 \\
$\mathrm{C} 6-\mathrm{C} 1-\mathrm{C} 2$ & $116.5(3)$ & $\mathrm{H} 8-\mathrm{C} 8-\mathrm{H} 10$ & $128.9(3)$ \\
$\mathrm{C} 6-\mathrm{C} 1-\mathrm{C} 9$ & $124.1(3)$ & $\mathrm{H} 9-\mathrm{C} 8-\mathrm{H} 10$ & 115.6 \\
$\mathrm{C} 2-\mathrm{C} 1-\mathrm{C} 9$ & $119.4(3)$ & $\mathrm{C} 10-\mathrm{C} 9-\mathrm{C} 1$ & 115.6 \\
$\mathrm{C} 3-\mathrm{C} 2-\mathrm{C} 1$ & $122.4(3)$ & $\mathrm{C} 10-\mathrm{C} 9-\mathrm{H} 11$ & $120.5(3)$ \\
$\mathrm{C} 3-\mathrm{C} 2-\mathrm{H} 1$ & 118.8 & $\mathrm{C} 1-\mathrm{C} 9-\mathrm{H} 11$ & \\
$\mathrm{C} 1-\mathrm{C} 2-\mathrm{H} 1$ & 118.8 & $\mathrm{C} 9-\mathrm{C} 10-\mathrm{C} 11$ &
\end{tabular}




\begin{tabular}{|c|c|c|c|}
\hline $\mathrm{C} 2-\mathrm{C} 3-\mathrm{C} 4$ & $120.7(3)$ & $\mathrm{C} 9-\mathrm{C} 10-\mathrm{H} 12$ & 119.7 \\
\hline $\mathrm{C} 2-\mathrm{C} 3-\mathrm{H} 2$ & 119.7 & $\mathrm{C} 11-\mathrm{C} 10-\mathrm{H} 12$ & 119.7 \\
\hline $\mathrm{C} 4-\mathrm{C} 3-\mathrm{H} 2$ & 119.7 & $\mathrm{O} 1-\mathrm{C} 11-\mathrm{C} 10$ & $122.8(3)$ \\
\hline $\mathrm{N} 1-\mathrm{C} 4-\mathrm{C} 3$ & $121.0(3)$ & $\mathrm{O} 1-\mathrm{C} 11-\mathrm{C} 12$ & $119.3(3)$ \\
\hline $\mathrm{N} 1-\mathrm{C} 4-\mathrm{C} 5$ & $121.9(3)$ & $\mathrm{C} 10-\mathrm{C} 11-\mathrm{C} 12$ & $117.9(3)$ \\
\hline $\mathrm{C} 3-\mathrm{C} 4-\mathrm{C} 5$ & $117.1(3)$ & $\mathrm{C} 13-\mathrm{C} 12-\mathrm{C} 11$ & $130.7(3)$ \\
\hline $\mathrm{C} 6-\mathrm{C} 5-\mathrm{C} 4$ & $121.0(3)$ & $\mathrm{C} 13-\mathrm{C} 12-\mathrm{S} 1$ & $111.0(2)$ \\
\hline $\mathrm{C} 6-\mathrm{C} 5-\mathrm{H} 3$ & 119.5 & $\mathrm{C} 11-\mathrm{C} 12-\mathrm{S} 1$ & $118.3(2)$ \\
\hline $\mathrm{C} 4-\mathrm{C} 5-\mathrm{H} 3$ & 119.5 & $\mathrm{C} 12-\mathrm{C} 13-\mathrm{C} 14$ & $112.3(3)$ \\
\hline $\mathrm{C} 5-\mathrm{C} 6-\mathrm{C} 1$ & $122.2(3)$ & $\mathrm{C} 12-\mathrm{C} 13-\mathrm{H} 13$ & 123.8 \\
\hline $\mathrm{C} 5-\mathrm{C} 6-\mathrm{H} 4$ & 118.9 & $\mathrm{C} 14-\mathrm{C} 13-\mathrm{H} 13$ & 123.8 \\
\hline $\mathrm{C} 1-\mathrm{C} 6-\mathrm{H} 4$ & 118.9 & $\mathrm{C} 15-\mathrm{C} 14-\mathrm{C} 13$ & $112.7(3)$ \\
\hline $\mathrm{N} 1-\mathrm{C} 7-\mathrm{H} 5$ & 109.5 & $\mathrm{C} 15-\mathrm{C} 14-\mathrm{H} 14$ & 123.6 \\
\hline $\mathrm{N} 1-\mathrm{C} 7-\mathrm{H} 6$ & 109.5 & $\mathrm{C} 13-\mathrm{C} 14-\mathrm{H} 14$ & 123.6 \\
\hline $\mathrm{H} 5-\mathrm{C} 7-\mathrm{H} 6$ & 109.5 & $\mathrm{C} 14-\mathrm{C} 15-\mathrm{S} 1$ & $112.1(3)$ \\
\hline $\mathrm{N} 1-\mathrm{C} 7-\mathrm{H} 7$ & 109.5 & $\mathrm{C} 14-\mathrm{C} 15-\mathrm{H} 15$ & 124.0 \\
\hline $\mathrm{H} 5-\mathrm{C} 7-\mathrm{H} 7$ & 109.5 & $\mathrm{~S} 1-\mathrm{C} 15-\mathrm{H} 15$ & 124.0 \\
\hline $\mathrm{H} 6-\mathrm{C} 7-\mathrm{H} 7$ & 109.5 & $\mathrm{C} 4-\mathrm{N} 1-\mathrm{C} 7$ & $120.9(3)$ \\
\hline $\mathrm{N} 1-\mathrm{C} 8-\mathrm{H} 8$ & 109.5 & $\mathrm{C} 4-\mathrm{N} 1-\mathrm{C} 8$ & $120.1(3)$ \\
\hline $\mathrm{N} 1-\mathrm{C} 8-\mathrm{H} 9$ & 109.5 & $\mathrm{C} 7-\mathrm{N} 1-\mathrm{C} 8$ & $117.8(3)$ \\
\hline $\mathrm{H} 8-\mathrm{C} 8-\mathrm{H} 9$ & 109.5 & $\mathrm{C} 15-\mathrm{S} 1-\mathrm{C} 12$ & $91.87(16)$ \\
\hline $\mathrm{N} 1-\mathrm{C} 8-\mathrm{H} 10$ & 109.5 & & \\
\hline $\mathrm{C} 6-\mathrm{C} 1-\mathrm{C} 2-\mathrm{C} 3$ & $-0.9(5)$ & $\mathrm{O} 1-\mathrm{C} 11-\mathrm{C} 12-\mathrm{C} 13$ & $175.7(3)$ \\
\hline $\mathrm{C} 9-\mathrm{C} 1-\mathrm{C} 2-\mathrm{C} 3$ & $179.7(3)$ & $\mathrm{C} 10-\mathrm{C} 11-\mathrm{C} 12-\mathrm{C} 13$ & $-5.9(5)$ \\
\hline $\mathrm{C} 1-\mathrm{C} 2-\mathrm{C} 3-\mathrm{C} 4$ & $0.0(5)$ & $\mathrm{O} 1-\mathrm{C} 11-\mathrm{C} 12-\mathrm{S} 1$ & $-2.0(4)$ \\
\hline $\mathrm{C} 2-\mathrm{C} 3-\mathrm{C} 4-\mathrm{N} 1$ & $179.7(3)$ & $\mathrm{C} 10-\mathrm{C} 11-\mathrm{C} 12-\mathrm{S} 1$ & $176.4(2)$ \\
\hline $\mathrm{C} 2-\mathrm{C} 3-\mathrm{C} 4-\mathrm{C} 5$ & $0.5(5)$ & $\mathrm{C} 11-\mathrm{C} 12-\mathrm{C} 13-\mathrm{C} 14$ & $-177.5(3)$ \\
\hline $\mathrm{N} 1-\mathrm{C} 4-\mathrm{C} 5-\mathrm{C} 6$ & $-179.3(3)$ & $\mathrm{S} 1-\mathrm{C} 12-\mathrm{C} 13-\mathrm{C} 14$ & $0.3(4)$ \\
\hline $\mathrm{C} 3-\mathrm{C} 4-\mathrm{C} 5-\mathrm{C} 6$ & $0.0(5)$ & $\mathrm{C} 12-\mathrm{C} 13-\mathrm{C} 14-\mathrm{C} 15$ & $-1.0(4)$ \\
\hline $\mathrm{C} 4-\mathrm{C} 5-\mathrm{C} 6-\mathrm{C} 1$ & $-0.9(5)$ & $\mathrm{C} 13-\mathrm{C} 14-\mathrm{C} 15-\mathrm{S} 1$ & $1.2(4)$ \\
\hline $\mathrm{C} 2-\mathrm{C} 1-\mathrm{C} 6-\mathrm{C} 5$ & $1.3(5)$ & $\mathrm{C} 3-\mathrm{C} 4-\mathrm{N} 1-\mathrm{C} 7$ & $179.1(3)$ \\
\hline $\mathrm{C} 9-\mathrm{C} 1-\mathrm{C} 6-\mathrm{C} 5$ & $-179.3(3)$ & $\mathrm{C} 5-\mathrm{C} 4-\mathrm{N} 1-\mathrm{C} 7$ & $-1.7(5)$ \\
\hline $\mathrm{C} 6-\mathrm{C} 1-\mathrm{C} 9-\mathrm{C} 10$ & $-2.8(5)$ & $\mathrm{C} 3-\mathrm{C} 4-\mathrm{N} 1-\mathrm{C} 8$ & $11.2(5)$ \\
\hline $\mathrm{C} 2-\mathrm{C} 1-\mathrm{C} 9-\mathrm{C} 10$ & $176.5(3)$ & $\mathrm{C} 5-\mathrm{C} 4-\mathrm{N} 1-\mathrm{C} 8$ & $-169.6(3)$ \\
\hline $\mathrm{C} 1-\mathrm{C} 9-\mathrm{C} 10-\mathrm{C} 11$ & $179.2(3)$ & $\mathrm{C} 14-\mathrm{C} 15-\mathrm{S} 1-\mathrm{C} 12$ & $-0.9(3)$ \\
\hline $\mathrm{C} 9-\mathrm{C} 10-\mathrm{C} 11-\mathrm{O} 1$ & $-4.9(5)$ & $\mathrm{C} 13-\mathrm{C} 12-\mathrm{S} 1-\mathrm{C} 15$ & $0.3(3)$ \\
\hline $\mathrm{C} 9-\mathrm{C} 10-\mathrm{C} 11-\mathrm{C} 12$ & $176.7(3)$ & $\mathrm{C} 11-\mathrm{C} 12-\mathrm{S} 1-\mathrm{C} 15$ & $178.4(3)$ \\
\hline
\end{tabular}

Hydrogen-bond geometry $\left(A,{ }^{\circ}\right)$

$C g$ is the centroid of the $\mathrm{S} 1 / \mathrm{C} 12-\mathrm{C} 15$ thiophene ring.

\begin{tabular}{lllll}
\hline$D-\mathrm{H} \cdots A$ & $D-\mathrm{H}$ & $\mathrm{H} \cdots A$ & $D \cdots A$ & $D-\mathrm{H} \cdots A$ \\
\hline $\mathrm{C} 13-\mathrm{H} 13 \cdots \mathrm{O} 1^{\mathrm{i}}$ & 0.95 & 2.65 & $3.451(4)$ & 142 \\
$\mathrm{C} 14-\mathrm{H} 14 \cdots \mathrm{S}^{\mathrm{i}}$ & 0.95 & 3.00 & $3.779(3)$ & 141
\end{tabular}


$\mathrm{C} 15-\mathrm{H} 15 \cdots \mathrm{O} 1^{\mathrm{ii}}$

$\mathrm{C} 8-\mathrm{H} 8 \cdots \mathrm{Cg}^{\mathrm{iii}}$

Symmetry codes: (i) $x+1, y, z$; (ii) $-x-1 / 2, y-1 / 2,-z+3 / 2$; (iii) $-x,-y,-z+1$.
2.57

2.64
$3.291(4)$

3.457 (4)
133

141 